ISSN 1027-5495. Functional Materials, 23, No.3 (2016), p. 468-472

doi:http://dx.doi.org/10.15407/fm23.03.468

(C) 2016 - STC “Institute for Single Crystals"

\title{
Compressive test and simulation of cassava stems using ANSYS
}

\author{
Zhang Jin', Xue Zhong ${ }^{1,2}$, Zhang Yanlin', Song Deqing ${ }^{1}$ \\ ${ }^{1}$ College of Engineering and Technology, Huazhong Agricultural \\ University, Wuhan, Hubei, 430070, P.R.China \\ ${ }^{2}$ Institute of Agricultural Machinery, Chinese Academy of Tropical \\ Agricultural Sciences, Zhanjiang, Guangdong, 524091, P.R.China
}

Received March 23,2016

\begin{abstract}
Compression tests were conducted on cassava stems with a universal testing machine in order to determine their compressive strength limits, or the points at which the stems began to deform plastically. Based on the test, ANSYS, a universal finite element analysis (FEA) software, was used to construct the mechanical models of the cassava stems and analyze the displacements, stresses, and shear stresses within the stems as they broke under compressive loads. Keywords: cassava, compression, simulation, ANSYS.
\end{abstract}

Компрессионные испытания проводились на стеблях маниока на универсальной испытательной машине для того, чтобы определить их пределы прочности, или точки, в которых стебли пластически деформируются. На основании теста, при помощи программы ANSYS, методом конечных элементов (FEA) была построена модель определения механической прочности стеблей маниоки и проанализированы напряжения сдвига в стеблях при сжимающих нагрузках.

Випробування на стиск і моделювання напружень маніока методом ANSYS. Чжан Иін, Сюе :Жонг, Чжан Яньлінь, Сонг Декинг

Компресійні випробування проводилися на стеблах маніока на універсальної випробувальної машині для того, щоб визначити їх межі міцності, або точки, в яких стебла пластично деформуються. На підставі тесту, за допомогою програми ANSYS, методом кінцевих елементів (FEA) була побудована модель визначення механічної міцності стебел маніоки і проаналізовані напруги зсуву в стеблах при стискають навантаженнях.

\section{Introduction}

Cassava, one of the three main root and tuber crops (i.e., cassava, sweet potato, and potato) [1], is one of the world's most important food crops, ranking fourth after wheat, rice, and maize. It is also an economically important crop due to its multiple uses, for example, as a raw material for starch and alcohol production [2-5]. While the tuberous roots of this crop are widely used, its stem is usually discarded during harvest and production [6]. However, the stems of this crop can be used not only as veg- etative reproduction material, but also as a raw material for biomass fuel production through fermentation [7-8]. Crushed cassava stems can be used as a substrate for edible mushrooms [9] and as organic fertilizer [10-11]. Currently, recycling cassava stems requires some treatments, such as cutting and crushing. Since few studies on the mechanical properties of cassava stems exist, the mechanical treatment of cassava stems is inefficient.

Research on the mechanical properties of plant stems has typically been conducted on the 
basis of traditional mechanical experiments. However, due to the development of computer technologies, studies using FEA software to model stems have also yielded satisfactory results. The mechanical properties of ramie stems processed on a hemp scraper have been studied using ANSYS software [12]. This software was also used to research the influence of sugarcane internodes on the mechanical properties of stems [13]. In another study, the mechanical conditions of corn stems subjected to a harvester were simulated with ANSYS and ADAM software [14].

In this paper, in order to research the mechanical properties of cassava stems, the mechanical conditions of cassava stem models as they reached the critical point, the point at which their mechanical behavior shifted from elastic deformation to plastic deformation, were studied. Highly efficient and reliable simulation and analyses were performed with ANSYS using the mechanical data of cassava stems. With this method, the limitations of time, space, and resources that physical experiments are subject to were avoided.

\section{Experimental}

\subsection{Material Preparation}

The Huanan 205 cassava samples used in this study were collected from the Tropical Agricultural Machinery Research Institute of the Chinese Academy of Tropical Agricultural Sciences in mid-December, 2013. On average, the cassava stems were $2.2 \mathrm{~m}$ long, $30 \mathrm{~mm}$ in diameter, and had $63.66 \%$ water content. The straight and healthy stems were selected for the test. After removing the branches from the stems, sections ranging from 50 to $150 \mathrm{~mm}$ above the stem bottoms were removed and used as the samples. Ten standard samples were obtained. Their outer diameters were $29 \mathrm{~mm} \pm 0.5 \mathrm{~mm}$, their inner diameters were

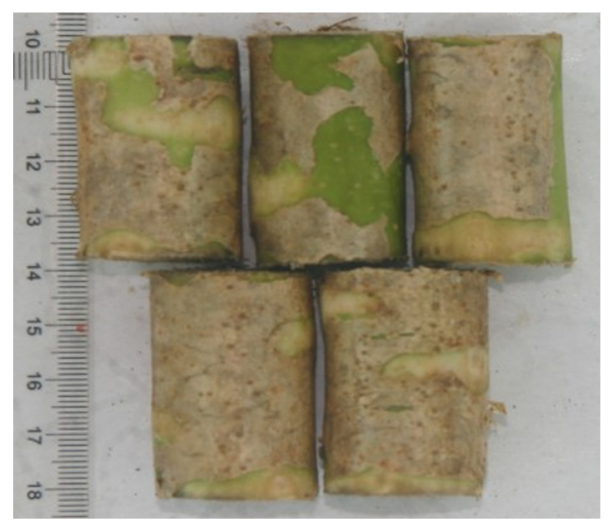

Fig. 1. Complete cassava stem sample

$13 \mathrm{~mm} \pm 0.5 \mathrm{~mm}$, and their lengths were $40 \mathrm{~mm}$ $( \pm 1 \mathrm{~mm})$, as shown in Fig. 1 .

\subsection{Test Method}

The samples were separated into two equal groups for testing. One group was used for the axial compression test, and the other was used for the radial compression test. The feeding rate of the universal testing machine during the tests was $20 \mathrm{~mm} / \mathrm{min}$. Fig. $2 \mathrm{a}$ and Fig. $2 \mathrm{~b}$ display the stress-displacement curves of the samples during the axial and radial compression tests, respectively.

As shown in Fig. 2, the average breaking point of the samples (the stress at which the stems began to deform plastically) subjected to the axial compressive load was approximately $4264 \mathrm{~N}$, and the average breaking point of the samples subjected to the radial compressive load was approximately $600 \mathrm{~N}$.

\subsection{Simplification of the model}

Cassava is a perennial shrub. Cassava stems are upright, and usually 2 to $5 \mathrm{~m}$ high. Numerous branches arise randomly from the main stems, with two vertically adjacent branches 20-60 mm in distance. From the center to the periphery, the cassava stem consists

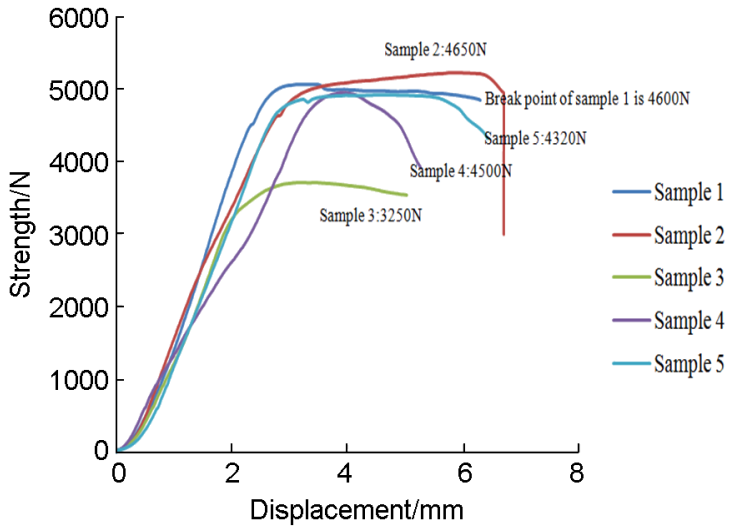

a)

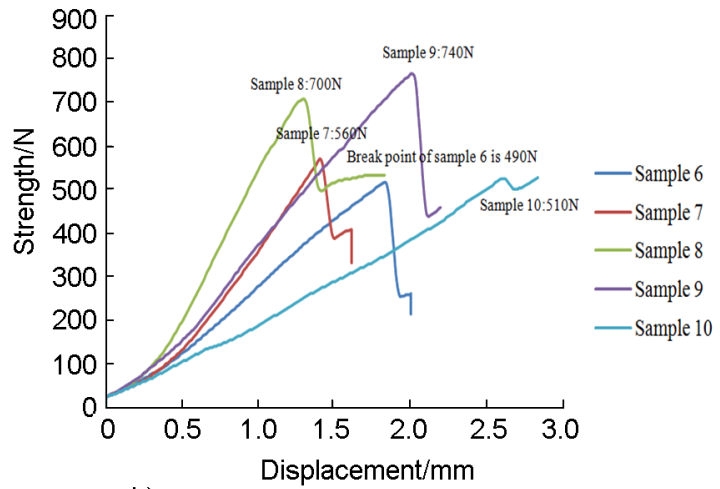

b)

Fig. 2. Axial and radial stress-displacement curves of the cassava stems 
Zhang Jin et al. / Compressive test and simulation of ...

Table 1. Material Parameter and Value

\begin{tabular}{|c|c|c|c|c|c|}
\hline \multirow{10}{*}{ Xylem } & $\begin{array}{l}\text { Material } \\
\text { Parameter }\end{array}$ & Value & & Material Parameter & Value \\
\hline & $\mathrm{EX} / \mathrm{Pa}$ & $5.001 \mathrm{E} 7$ & Bast fiber & $\mathrm{EX} / \mathrm{Pa}$ & $1.78 \mathrm{E} 6$ \\
\hline & $\mathrm{EY} / \mathrm{Pa}$ & $5.001 \mathrm{E} 7$ & & $\mathrm{EY} / \mathrm{Pa}$ & $1.78 \mathrm{E} 6$ \\
\hline & $\mathrm{EZ} / \mathrm{Pa}$ & $2.5042 \mathrm{E} 8$ & & $\mathrm{EZ} / \mathrm{Pa}$ & $1.224 \mathrm{E} 7$ \\
\hline & NUXY & 0.53 & & NUXY & 0.5 \\
\hline & NUYZ & 0.43 & & NUYZ & 0.38 \\
\hline & NUXZ & 0.43 & & NUXZ & 0.38 \\
\hline & $\mathrm{GXY} / \mathrm{Pa}$ & $1.634 \mathrm{E} 7$ & & $\mathrm{GXY} / \mathrm{Pa}$ & $5.9 \mathrm{E} 5$ \\
\hline & $\mathrm{GYZ} / \mathrm{Pa}$ & $1.634 \mathrm{E} 7$ & & $\mathrm{GYZ} / \mathrm{Pa}$ & $4.43 \mathrm{E} 6$ \\
\hline & $\mathrm{GXZ} / \mathrm{Pa}$ & $8.756 \mathrm{E} 7$ & & $\mathrm{GXZ} / \mathrm{Pa}$ & $4.43 \mathrm{E} 6$ \\
\hline
\end{tabular}

of the pith, xylem, and bast fiber, as shown in the cross section Fig. 3a. The pith, a soft tissue, has relatively poor mechanical properties compared to the xylem and bast fiber.

During modeling, the structure of the cassava stem was simplified as a laminated composite structure composed of only two parts: the bast fiber and the xylem. A hollow cylindrical model was constructed in this way, as shown in Fig. 3b.

\subsection{Modeling the cassava stem}

In order to improve the efficiency and accuracy of the computations, the hollow cylindrical model of the cassava stem was subdivided into two models according to the axial symmetry: the $1 / 4$ model, which was specific to the axial compression simulation, and the 1/2 model, which was specific to the radial compression simulation.

The model's element and material types were determined according to the requirements of the different models and analyses. The different parts of the cassava stems were distributed in a symmetric radial pattern. Due to its axial symmetry, the model was subdivided radially into elements with six faces. Then, considering the type of material and the requirements of the simulation and analysis, a three-dimensional solid element, SOLID186, was selected for the purposes of this study.

Although the xylem and bast fibers of cassava stems are horizontally isotropic materials, orthotropic material was used for the model according to the ANSYS software instructions. Orthotropic materials have nine independent elasticity coefficients. Values of each of the parameters influenced by the isotropic faces were assumed to be equal. The material parameters of the xylem and bast fiber are shown in Table 1 .

The ANSYS model was completed through the following process: Main Menu $\rightarrow$ Preprocessor $\rightarrow$ Modeling $\rightarrow$ Create $\rightarrow$ Volumes $\rightarrow$
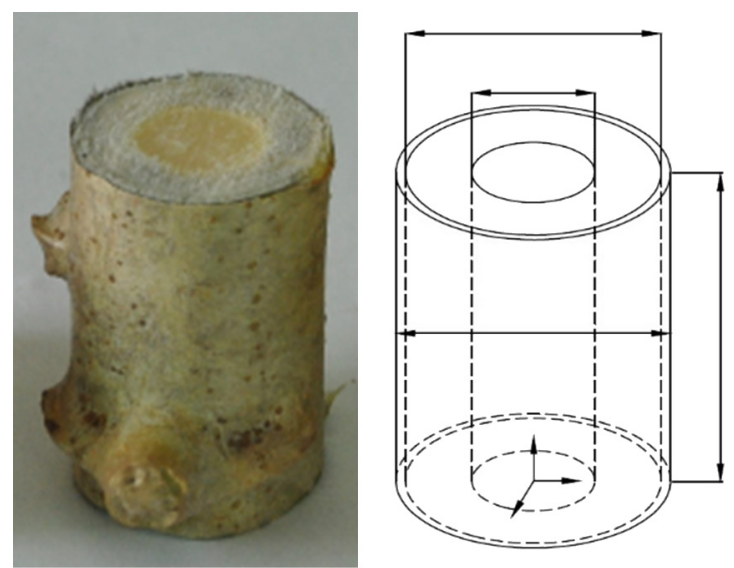

Fig. 3. Cassava stem model

Cylinder $\rightarrow$ Partial Cylinder. Then, the parameters were entered in the Partial Cylinder popup dialog box in order to model the xylem and the bast fiber separately.

Considering the laminated composite structure described previously and the continuity of the composite material's deformation, the Glue command was executed between the xylem and the bast fiber during the modeling process.

\subsection{Mesh generation}

Mapping was used to generate the mesh of the cassava stem models. First, Quad was implemented to create a quadrangle grid on the bottoms of the models. Then, Sweep was used to complete the mesh generation throughout the models.

The lengths of the xylem and bast fiber grid elements in the $1 / 4$ model axial compression simulation were $0.001(1 \mathrm{~mm})$ and 0.0004 $(0.4 \mathrm{~mm})$, respectively. The final $1 / 4$ model had 31641 nodes and 6840 elements (Fig. 4a).

In order to facilitate the computation of the $1 / 2$ model's radial compression simulation, the number of elements and nodes were reduced by decreasing the length of the bast fiber to 0.0006 $(0.6 \mathrm{~mm})$. The final $1 / 2$ model had 38139 nodes and 8208 elements (Fig. 4b). 


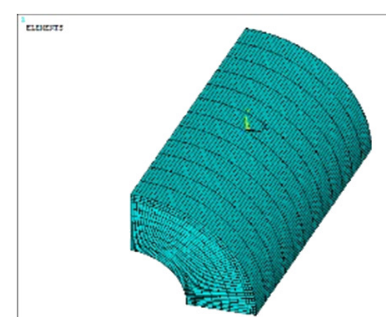

a) 1/4 model

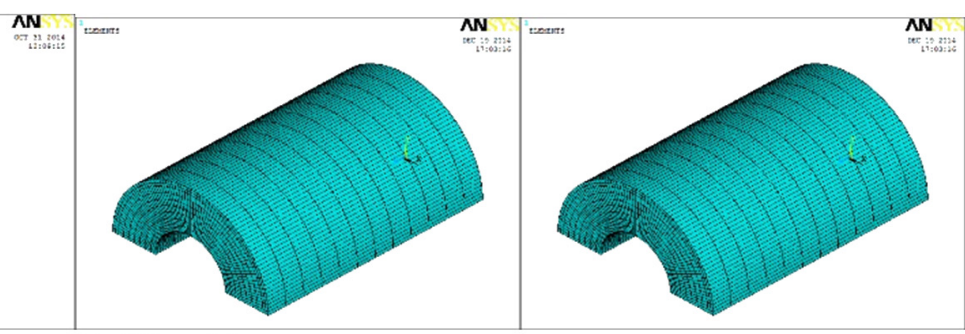

b) $1 / 2$ model

Fig. 4. Final models

\subsection{Static simulation and analysis}

Static simulation and analysis were performed in order to analyze the mechanical conditions of the cassava stems subjected to axial compressive loads in the universal testing machine. The displacements, stresses, and shear stresses in the cassava stems were observed as elastic deformation terminated and plastic deformation occurred. Fig. 5a and Fig. 5b display the schematic diagrams of the axial and radial compression on the cassava stems in the universal testing machine.

\subsection{Constraints and loading}

Due to the subdivision, the models were subjected to additional constraints before loading. The normal displacements of the points in each axially symmetrical plane were assumed to be zero, and the displacements in the other directions were not restricted. Therefore, constraints were imposed on the degrees of freedom (DOF) of the cross sections in order to constrain their normal displacements.

According to the compressive tests, the average breaking point, at which the stems began to deform plastically under the axial compressive load, was approximately $4264 N$. Thus, for the 1/4 model, a uniform load of $1 / 4 \times 4264 N=$ $1066 \mathrm{~N}$ was imposed on one end of the model, while constraints were imposed on the DOF of the other end in order to constrain displacements in the axial direction. Fig. (6a) displays the simulation of the axial loading on the cassava stem.

A radial uniform load of $1 / 2 \times 600 N=300 N$ was applied to the linear region of the $1 / 2$ model corresponding to the boundary between the stem and the mobile platform. Constraints were imposed on the DOF of the linear region in order to restrict any radial displacements. Fig. 6b displays simulation of the radial loading on the cassava stem.

\section{Results and analysis}

After imposing the constraints and loads on the models, the following processes were executed in order to obtain the solutions: Main $\mathrm{Menu} \rightarrow$ Solution $\rightarrow$ Solve $\rightarrow$ Current LS. Then,

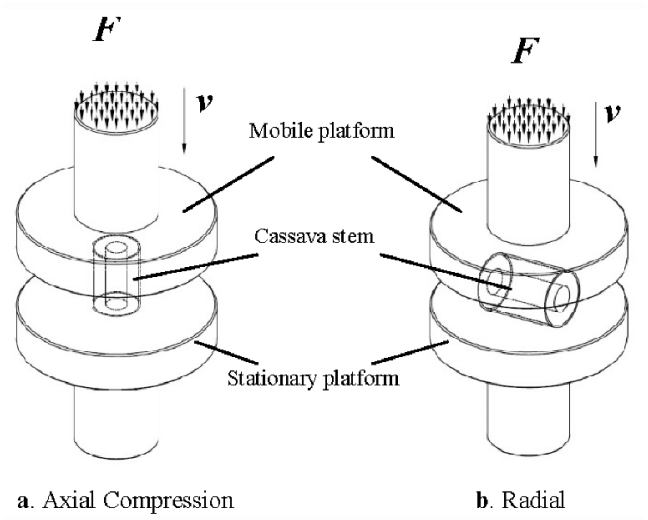

Fig. 5. Schematic diagrams of the axial and radial compressions on the cassava stems

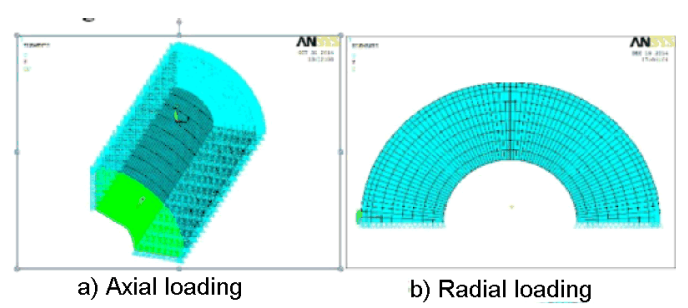

Fig. 6. Loading on the model

the nodal contour plots were obtained by implementing the following post-processing procedures: Main Menu $\rightarrow$ Plot Results $\rightarrow$ Contour Plot $\rightarrow$ Nodal Solu.

Fig. 7 displays the displacement plot, stress plot, XY shear stress plot, YZ shear stress plot, and XZ shear stress plot of the axially-loaded $1 / 4$ cassava stem model at the breaking point. At the breaking point, the displacements of the model under the axial compressive load ranged from $0.107 \mathrm{~mm}$ to $1.552 \mathrm{~mm}$; as shown in the plot, the maximum was observed at the boundary between the stem and the mobile platform. In addition, the stresses in the model varied from $0.47 \mathrm{Mpa}$ to $9.6 \mathrm{Mpa}$, and the maximum was located at the xylem. The shear stresses in the $\mathrm{XY}$ direction ranged from $-1785.7 \mathrm{~Pa}$ to 308.146 $\mathrm{Pa}$; the maximum shear stress, $-1785.7 \mathrm{~Pa}$, was observed in the bast fiber, and the minimum was observed in the xylem. In the YZ (XZ) direction, the shear stresses varied from -0.172156 Pa to 


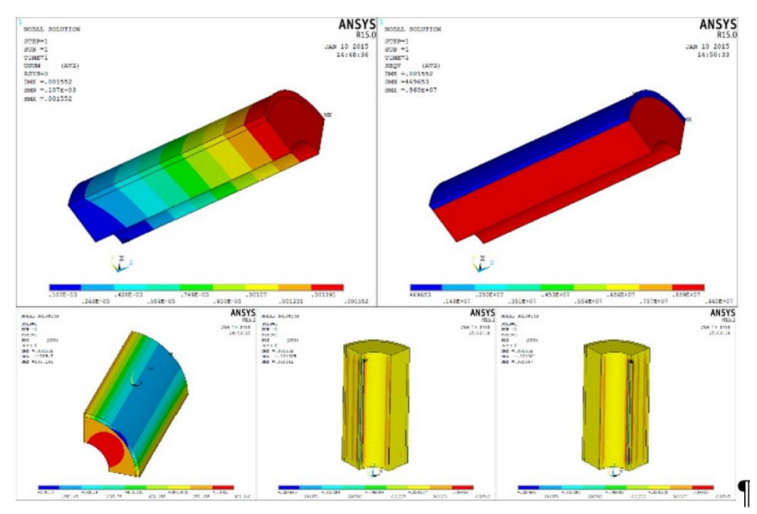

Fig. 7. Nodal contour plots of the $1 / 4$ model

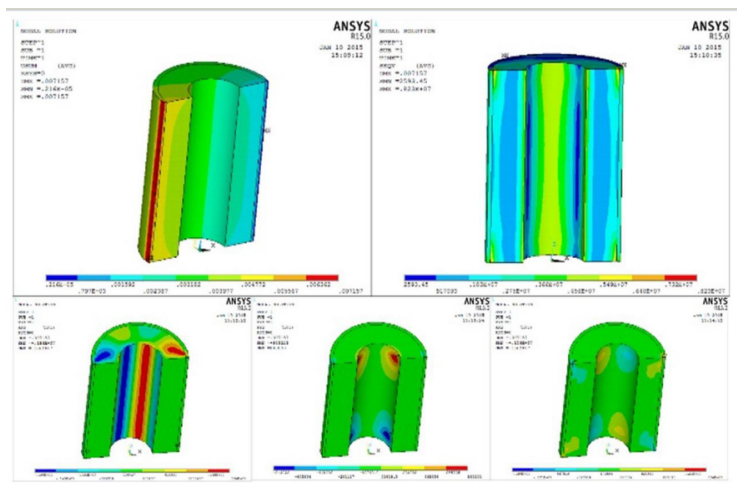

Fig. 8. Nodal contour plots of the $1 / 2$ model

$0.058631 \mathrm{~Pa}$; both the maximum and minimum were located in the interior of the xylem.

Fig. 8 displays the displacement plot, stress plot, XY shear stress plot, YZ shear stress plot, and $\mathrm{XZ}$ shear stress plot of the radially-loaded $1 / 2$ cassava stem model at the breaking point. The displacements ranged from $0.00216 \mathrm{~mm}$ to $7.157 \mathrm{~mm}$, and the maximum was observed at the boundary between the stems and the mobile platform. The stresses in this model ranged from $0.00259 \mathrm{Mpa}$ to $8.23 \mathrm{Mpa}$, and the maximum was located at the interface between the xylem and the bast fiber. The shear stresses ranged from $0.206437 \mathrm{Mpa}$ a to $1.86 \mathrm{Mpa}$ in the XY direction. The shear stress in the YZ direction ranged from $0.09362 \mathrm{Mpa}$ to 0.84309 Mpa, and the maximum was observed in the xylem; the shear stress in the XZ direction ranged from $0.173504 \mathrm{Mpa}$ to $1.56 \mathrm{Mpa}$. The maximum was located at the interface between the xylem and the bast fiber.

\section{Conclusions}

The compressive strengths of the cassava stems under radial and axial loads were determined with compression tests using a universal testing machine.

Based on the test results and the mechanical data of the xylem and bast fibers of cassava stems, the ANSYS simulation and analysis was conducted to study the displacements, stresses, and shear stresses of the cassava stem models at the breaking points.

The research results were inevitably influenced by the accuracy of the basic data used in the ANSYS simulation and the computer's operational performance. Therefore, improvement in these aspects would increase the accuracy of future simulation research results.

\section{Acknowledgments}

This research work was supported by the National Science Foundation of Guangdong Province-Creative Talents Joint Training Project of Eastern and Northwest Guangdong (2014A030307034), the Special Fund for Agro-scientific Research in the Public Interest (201203072), the Natural Science Foundation of Hainan Province (513149).

\section{References}

1. Z. Xue, X. M. Guo, Z. M. Huang, et al, J. Chinese Agricul. Mech., 35, 83, 2014.

2. X. L. Luo, Tillage a Cultiv, 1, 59, 2001.

3. G. C. Tao, G. H. Xie, Hakan Orberg, et al, Mater. Eng. Scie., 13, 107, 2011.

4. X. L. Luo, T. Y. Lao, Chinese Agricul. Scie.Bull., 17, 22, 2001.

5. S. J. Jin, S. F. Sun, A. P. Song, et al, , Sino-Global Energy, 16, 40, 2011.

6. Q. Q. Qiu, D. Liang. Popular Scie Techn., 14, 187, 2012.

7. H. L. Zhou, J. Sun, L. Chen, et al, Proceedings of the 9th Annual Academic Conference on Chinese Chemical Engineering, Changchun, China, 2005, 5, 338, 2005.

8. J. Gao, Analysis of the Pyrolytic Characteristics of Cassava Stems Based on Biomass Gasification Experiment, MS. South China University of Technology, China, 2005.

9. C. D. Qin, New Rural Techn., 2013, 13, 2013.

10. Y. Q. Zheng, M. Q. Bao, J. Q. Ye, Guangxi Agricul. Scie., 40, 1546, 2009.

11. H. Y.Li, X. L. Luo, Y. S. Liu, et al, Guangxi Agricul. Scie., 40, 705, 2009.

12. G. B. Su, Properties and Modelling Methods of Mechanics on Stems of Ramie, MS. Huazhong Agricultural University, China, 2007.

13. Y. Cui. On the Mechanical Model and Stress Analysis for Plant Stem with Core, MS. China Agricultural University, China, 2005.

14. T. Cui, J. Liu, D. X. Zhang, et al, Flexible Body Simulation for Corn Stem Based on ANSYS and ADAM, Transactions of the Chinese Society for Agricultural Machinery, 43, 112, 2012. 